\title{
Antioxidant, Immunomodulating, and Microbial-Modulating Activities of the Sustainable and Ecofriendly Spirulina
}

\author{
Alberto Finamore, ${ }^{1}$ Maura Palmery, ${ }^{2}$ Sarra Bensehaila, ${ }^{3}$ and Ilaria Peluso ${ }^{1}$ \\ ${ }^{1}$ Center of Nutrition, Council for Agricultural Research and Economics (CREA-NUT), Via Ardeatina 546, 00178 Rome, Italy \\ ${ }^{2}$ Department of Physiology and Pharmacology "V. Erspamer", "Sapienza" University of Rome, Rome, Italy \\ ${ }^{3}$ Laboratory of Natural and Local Bioresources, Department of Biology, Faculty of Sciences, University of Hassiba Benbouali, \\ 02000 Chlef, Algeria
}

Correspondence should be addressed to Ilaria Peluso; i.peluso@tiscali.it

Received 8 September 2016; Revised 26 November 2016; Accepted 12 December 2016; Published 15 January 2017

Academic Editor: Giuseppe Cirillo

Copyright (C) 2017 Alberto Finamore et al. This is an open access article distributed under the Creative Commons Attribution License, which permits unrestricted use, distribution, and reproduction in any medium, provided the original work is properly cited.

\begin{abstract}
The highly nutritional and ecofriendly Spirulina (Arthrospira platensis) has hypolipidemic, hypoglycemic, and antihypertensive properties. Spirulina contains functional compounds, such as phenolics, phycocyanins, and polysaccharides, with antioxidant, anti-inflammatory, and immunostimulating effects. Studies conducted on Spirulina suggest that it is safe in healthy subjects, but attitude to eating probably affects the acceptability of Spirulina containing foods. Although the antioxidant effect of Spirulina is confirmed by the intervention studies, the concerted modulation of antioxidant and inflammatory responses, suggested by in vitro and animal studies, requires more confirmation in humans. Spirulina supplements seem to affect more effectively the innate immunity, promoting the activity of natural killer cells. The effects on cytokines and on lymphocytes' proliferation depend on age, gender, and body weight differences. In this context, ageing and obesity are both associated with chronic low grade inflammation, immune impairment, and intestinal dysbiosis. Microbial-modulating activities have been reported in vitro, suggesting that the association of Spirulina and probiotics could represent a new strategy to improve the growth of beneficial intestinal microbiota. Although Spirulina might represent a functional food with potential beneficial effects on human health, the human interventions used only supplements. Therefore, the effect of food containing Spirulina should be evaluated in the future.
\end{abstract}

\section{Introduction}

Spirulina (Arthrospira platensis) is a microscopic and filamentous cyanobacterium that has been suggested as a sustainable and ecofriendly microalga useful for bioremediation, nitrification, and carbon dioxide $\left(\mathrm{CO}_{2}\right)$ fixation. In the context of the bioremediation, Spirulina is considered a candidate for the removal of toxicants, such as heavy metals [1-5] and phenol [6]. Besides, within microalgae and cyanobacteria Spirulina showed maximum biomass productivity with the highest $\mathrm{CO}_{2}$ fixation rate [7] and it has been suggested for the nitrification from urine in urban wastewaters [8]. The environmentally friendly Spirulina does not need fertile land, has a rapid growth, and takes less energy input and less water per kilogram than soya and corn proteins [9]. Due to its costeffective and high nutritional value Spirulina has been used as protein-rich animal feed for improving meat production and quality [10] and has been proposed as a sustainable approach to prevent Protein Energy Malnutrition (PEM) and Protein Energy Wasting (PEW) in humans [9].

On the other hand, Spirulina presents hypolipidemic [11], hypoglycemic [12], and antihypertensive [13] properties. Studies in rats suggested that Spirulina increases the lipoprotein lipase activity [14] and the pancreatic secretion of insulin [15]. The latter effect was observed also in mice treated with phycocyanin isolated from Spirulina and was accompanied by a decrease in cholesterol, triglycerides, and malondialdehyde (MDA) and by an increase in the serum total antioxidant capacity [16]. On the other hand, the oral administration of an antihypertensive peptide, purified by Spirulina and resistant to in vitro digestion by gastrointestinal proteases, decreased 
both systolic (SBP) and diastolic (DBP) blood pressure in spontaneously hypertensive rats [17].

All these effects could be considered useful in the prevention of the metabolic syndrome. In fact, according to the World Health Organization (WHO), high serum triglyceride level, low serum high-density lipoprotein (HDL) cholesterol level, hypertension, and elevated fasting blood glucose are four of the five risk factors (three out of the five required) for the diagnosis of metabolic syndrome [18]. Metabolic syndrome is associated with subclinical low grade inflammation, oxidative stress, and intestinal dysbiosis and it has been suggested that the gut microbiota could be a target for nutraceuticals [18]. In this regard, in vitro antimicrobial activity [19-21] and the capacity to improve the growth of probiotics [22-24] have been reported for Spirulina.

Furthermore, Spirulina contains many functional bioactive ingredients with antioxidant and anti-inflammatory activities, including phenolic phytochemicals $[25,26]$ and the phycobiliprotein C-phycocyanin [27].

We aimed to evaluate the possibility that Spirulina could be an antioxidant and immunomodulating functional food by reviewing the human evidences, after taking into account safety and acceptability aspects.

\section{Functional Compounds of Spirulina}

Spirulina has high nutritional values due to its content in proteins, essential amino acids, minerals, essential fatty acids, vitamins, and liposoluble antioxidants (vitamin E and carotenoids) [28-38] (Table 1).

Great attention has been given to Spirulina antioxidant and anti-inflammatory activities in many animal species $[16$, 34, 38-50] that could not be explained only by Spirulina macro and micronutrient content (Table 1).

It has been suggested that the antioxidant activity accounts for the protective role of Spirulina against the toxicity induced by carbon tetrachloride (CCl4) [40], by metals (arsenic, mercuric chloride, chromium, cadmium, and fluoride) [34, 41-44], by the insecticide deltamethrin in mice [39] and rats [45], and by the drugs tilmicosin (in mice) [46], gentamicin (in rats) [47], and erythromycin in Egyptian Baladi bucks (Capra hircus) [38].

Furthermore, antioxidant effects of Spirulina have been reported also in murine models of inflammation [48-50]. In rat models of experimental colitis (acetic-acid induced) [48] and arthritis (Freund's adjuvant-induced [49] and collageninduced [50]) the antioxidant activity of Spirulina was associated with anti-inflammatory effects. Abdel-Daim et al. [39] recently observed a decrease of the proinflammatory cytokine tumor necrosis factor-alpha (TNF- $\alpha$ ) in serum and at the same time an improvement of oxidative stress markers [malondialdehyde (MDA), nitric oxide (NO), superoxide dismutase (SOD), catalase (CAT), reduced glutathione (GSH), and glutathione peroxidase (GPX)] in hepatic, renal, and brain tissues, by using Spirulina platensis powder (500 and $1000 \mathrm{mg} / \mathrm{kg}) 1 \mathrm{~h}$ before deltamethrin $(15 \mathrm{mg} / \mathrm{kg})$ in mice [39].

$\mathrm{Hu}$ et al. [51] suggested a potential concerted modulation of nuclear factor-erythroid 2-related factor 2 (Nfr2)/antioxidant responsive elements (ARE) and nuclear factor-kappa
TABLE 1: Nutritional values and functional compounds of Spirulina.

\begin{tabular}{|c|c|c|c|}
\hline & Content in $100 \mathrm{~g}$ & $\begin{array}{l}\text { The effects in vitro } \\
\text { and in animal } \\
\text { models }\end{array}$ & Ref. \\
\hline $\begin{array}{l}\text { Nutritional } \\
\text { values }\end{array}$ & $\begin{array}{c}\text { Proteins 35.4-70.0 g } \\
\text { Amino } \\
\text { acids Glutamate } \\
\text { 7.0-7.3 g } \\
\text { Leucine } 5.9-8.4 \mathrm{~g} \\
\text { Aspartate } 5.2-6.0 \mathrm{~g} \\
\text { Lysine } 2.6-4.6 \mathrm{~g} \\
\text { Tyrosine } 2.6-3.4 \mathrm{~g} \\
\text { Phenylalanine } \\
\text { 2.6-4.1 g } \\
\text { Methionine } 1.3-2.7 \mathrm{~g} \\
\text { Fat 4.0-16.0 g } \\
\text { \% of total fatty } \\
\text { acidsPalmitic } \\
25.8-44.9 \% \\
\text { Gamma-linoleic } \\
17.1-40.1 \% \\
\text { Linoleic } 11.1-12.0 \% \\
\text { Oleic 10.1-16.6\% } \\
\text { Palmitoleic } 2.3-3.8 \% \\
\text { Stearic } 1.7-2.2 \% \\
\text { Carbohydrates } \\
14.0-19.0 \mathrm{~g} \\
\text { Crude fiber } 3.0-7.0 \mathrm{~g} \\
\text { Minerals } \\
\text { Potassium } 2.0-2.6 \mathrm{~g} \\
\text { Sodium } 1.5-2.2 \mathrm{~g} \\
\text { Total phosphorus } \\
1.3-2.2 \mathrm{~g} \\
\text { Iron 273.2-787.0 mg } \\
\text { Magnesium } 330 \\
\text { Calcium } 120-900 \mathrm{mg} \\
\text { Vitamins } \\
\text { B12 5.7-38.5 } \mu \mathrm{g} \\
\text { B2 3.0-4.6 mg } \\
\text { B6 0.5-0.8 mg } \\
\text { Niacin (B3) } 13-15 \mathrm{mg} \\
\text { Folic acid } \\
0.05-9.92 \mathrm{mg} \\
\text { Carotenoids } 0.3-2.6 \mathrm{~g} \\
\text { Tocopherol 0.4-9.8 g }\end{array}$ & & $\begin{array}{c}{[28-} \\
38]\end{array}$ \\
\hline \multirow{3}{*}{$\begin{array}{l}\text { Functional } \\
\text { compounds }\end{array}$} & $\begin{array}{c}\text { Total phenol } \\
0.20-1.73 \mathrm{~g} \\
\text { Flavonoids } 0.1-0.9 \mathrm{~g}\end{array}$ & $\begin{array}{c}\text { Antioxidant } \\
\text { Anti-inflammatory }\end{array}$ & $\begin{array}{l}{[25,26,} \\
83,84]\end{array}$ \\
\hline & $\begin{array}{c}\text { Phycocyanins } \\
\text { C-Phycocyanin } \\
\text { 13.5-14.8 g } \\
\text { Allophycocyanin } 2.3 \mathrm{~g} \\
\text { Phycobiliproteins } 1.1 \mathrm{~g}\end{array}$ & $\begin{array}{c}\text { Antioxidant } \\
\text { Anti-inflammatory }\end{array}$ & $\begin{array}{l}{[27,32} \\
34,36 \\
56-66]\end{array}$ \\
\hline & $\begin{array}{c}\text { Polysaccharides } \\
0.2-12.5 \mathrm{~g}\end{array}$ & Immunostimulating & $\begin{array}{c}{[69-} \\
72] \\
\end{array}$ \\
\hline
\end{tabular}

B (NF-kB) in inflammation and carcinogenesis. Many phenolic antioxidants $[52,53]$ and C-phycocyanin $[54,55]$ exert their anti-inflammatory and antioxidant effects through the integrated modulation of Nrf2 and NF-kB pathways. In 
particular, C-phycocyanin was able to inhibit NF-kB [54] and induced Nrf2 activation in pancreatic $\beta$-cell INS-1 [55]. Although Spirulina antioxidant and anti-inflammatory activities can be due to both phenolic compounds and phycocyanins, C-phycocyanin is contained in higher amounts (Table 1) and has been studied more in vitro [56-63] and in animal models $[27,57,64-66]$. In addition to the scavenging property of C-phycocyanin [56,57], in cellular models it exerted the antioxidant activity also regulating the antioxidant enzymes activity, such as SOD, CAT, and GPX [58] and inhibiting the cyclooxygenase-2 (COX-2) [63] and the inducible nitric oxide synthase (iNOS) gene expression [63]. Furthermore, a $50 \%$ inhibitory concentration (IC50) of $180 \mathrm{nM}$ has been found in a COX-2 isolated enzyme assay [62]. The effects of C-phycocyanin on COX-2 $[64,65]$ and iNOS [64] were also confirmed in animals, where a decrease of the proinflammatory TNF- $\alpha$ expression in the carragenan-induced rat paw [64] and of the TNF- $\alpha$ and interleukin- $1 \beta$ (IL- $1 \beta$ ) expression in the cochlea and inferior colliculus after salicylate-induced tinnitus in mice was observed [65]. Also Spirulina lipid extract [67] has been shown to repress proinflammatory cytokine (TNF- $\alpha$, IL- $1 \beta$, and IL-6) expression and secretion via inhibition of NF-kB pathway. Besides, Spirulina contains also heptadecane, a volatile component which has been shown to suppress proinflammatory gene expressions by reducing NF-kB activity [68]. However, it must be taken into account that polysaccharides [69] contained in Spirulina (Table 1) can induce NF-kB pathway. In particular, the high molecular weight polysaccharide Immulina has been reported have immunostimulatory activity [70-72] and increased IL- $1 \beta$ and TNF- $\alpha$ expression by inducing NFkappa B pathway [72]. Despite the fact that the immunostimulatory activity could increase inflammation, it must be taken into account that in syngeneic tumor-implant mice (C57BL/6 versus B16 melanoma) the antitumor activity and the increased NK cytotoxicity were observed in parallel with the production of interferon-gamma (IFN- $\gamma$ ) [73]. Furthermore, it was also observed that Spirulina consumption increased macrophage activation (phagocytic activity and nitrite production) in chicken [74]. Therefore, Spirulina could modulate immune function, reducing inflammation without inhibiting the innate immune defences.

\section{Microbial-Modulating Activities}

It has been recently reported that, in the majority of commercially available Spirulina food supplements, Arthrospira platensis was the predominant taxon (81.2-100.0\%) among the cyanobacteria [75].

Spirulina (Arthrospira) platensis is able to inhibit the growth of some Gram-negative (Escherichia coli, Pseudomonas aeruginosa, and Proteus vulgaris) and Gram-positive bacteria (Staphylococcus aureus, Bacillus subtilis, and Bacillus pumulis) [76]. In fact, Spirulina produces extracellular metabolites with antibacterial activity (Figure 1) [19-21, 77]. The methanol extract from grown culture medium of Spirulina showed a higher antimicrobial activity than hexane [21], dichloromethane $[20,21]$, petroleum ether [20], ethyl acetate $[20,21]$ extracts, and volatile components (heptadecane and tetradecane) [20], especially against Streptococcus faecalis [20], Staphylococcus epidermidis [20] and Candida albicans [20], Gram-positive bacterium Staphylococcus aureus [21], and Gram-negative bacterium Escherichia coli [21].

On the contrary, low (minimum inhibitory concentrations, MIC $\geq 512 \mu \mathrm{g} / \mathrm{ml}$ ) or no inhibitory effect was found against other bacteria (Pseudomonas aeruginosa, Salmonella typhirium, and Klebsiella pneumoniae) [21]. El-Sheekh et al. [19] purified an antimicrobial compound (molecular formula $\mathrm{C}_{15} \mathrm{H}_{18} \mathrm{NO}_{8}$ ) from Spirulina platensis with no characteristic odor and yellowish green color. This extract (soluble in methanol, diethyl ether, chloroform, and dimethyl sulfoxide, but sparingly soluble in water and acetone) was active against the unicellular fungus Candida albicans $(\mathrm{MIC}=30 \mu \mathrm{g} / \mathrm{ml}$ ) and the Gram-positive Bacillus subtilis (MIC $=60 \mu \mathrm{g} / \mathrm{ml}$ ) at lower concentrations in comparison to the effect against the Gram-negative bacterium Pseudomonas aeruginosa $(\mathrm{MIC}=$ $85 \mu \mathrm{g} / \mathrm{ml}$ ) [19]. Besides, Spirulina has been recently used in the synthesis of biofunctionalized gold nanoparticles with antibacterial activity against Gram-positive organisms (Bacillus subtilis and Staphylococcus aureus) [77]. Therefore, the research on advanced medical applications of Spirulinaderived products in the treatment of infectious diseases caused by Gram-positive organisms is growing (Figure 1).

On the other hand, it has also been reported that extracellular products of Spirulina, obtained from a culture in late exponential stage and separated by filtration, significantly promote the in vitro growth of the lactic acid bacteria (Lactococcus lactis, Streptococcus thermophilus, Lactobacillus casei, Lactobacillus acidophilus, and Lactobacillus bulgaricus) [22]. Probiotics, including the genera Lactobacillus and Bifidobacterium (Figure 1) [78], are largely used as starter bacteria for the production of yogurt [24], the most popular fermented diary product worldwide. Spirulina biomass has a stimulatory effect on the growth (during fermentation) and/or increases the survival (during storage) of Bifidobacterium [23, 24], Lactobacillus acidophilus [24, 76], Lactobacillus bulgaricus [7981], Lactobacillus casei [76], and Streptococcus thermophilus $[23,76,79,80,82]$.

Although the better growth and survival have been attributed to the high level of nitrogenous substances, in particular free amino acids, in the Spirulina biomass [109], also phenolic compounds have been shown to exert antimicrobial or bacteriostatic activities, as well as improving the growth of probiotics [18]. Therefore, the complex composition of Spirulina could improve the quality of fermented diary products and the supplementation with Spirulina might represent an alternative strategy to the synbiotics formulations. The latter appear more effective than probiotics alone in the prevention of the dysbiosis (Figure 1) associated with immune-mediated, inflammatory, and dysmetabolic diseases [78].

Despite the rich literature on in vitro effect of Spirulina, only few studies have been conducted in vivo. Although in mice the gut microbiota of the Spirulina-fed group was $70 \%$ similar to that of the control mice [110], changes of gut microbiota ecology induced by Spirulina feeding in mice have been showed by Rasmussen and collegues [110]. The authors observed that Spirulina plantensis leads change to gut microbiota composition in mice reducing Bifidobacterium animalis 


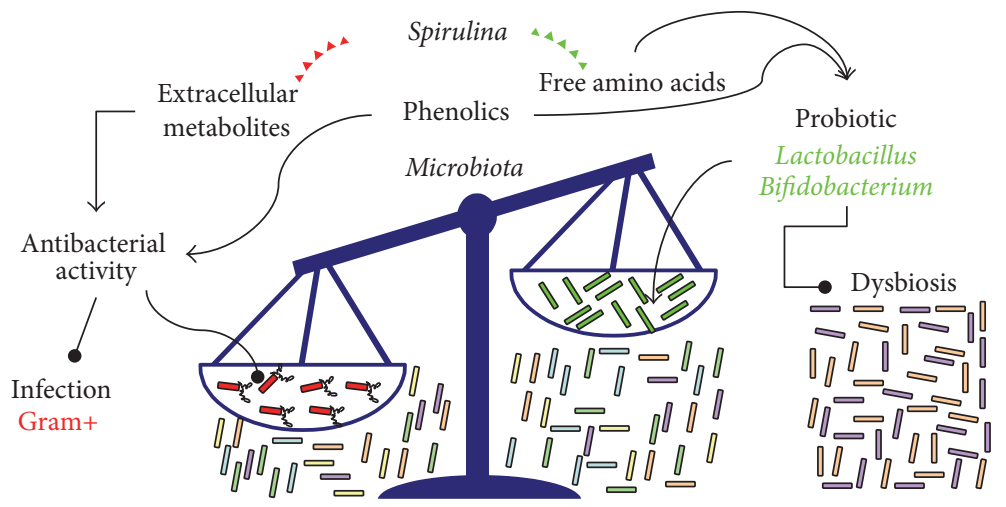

FIGURE 1: Microbial-modulating activities of Spirulina could prevent dysbiosis. The antibacterial activity of Spirulina could protect the host by infections. Changes in microbiota composition are commonly associated with several several diseases including inflammatory bowel diseases (IBD) and metabolic and immunological diseases. Alterations of gut microbial composition also result in changes in the metabolites generated in the gut from microbial activity, essential for a correct gut homeoastasis. Spirulina intake may favour a restabilishment of correct microbial balance by promoting probiotic species growth.

and increasing Clostridium irregulare, suggesting that numbers of this organism are modified through both blue-green algae supplements [110]. It is largely established that drastic changes of microbiota composition occur in several gastrointestinal, immunological, and metabolic diseases [111, 112]. In many microbiota related diseases, including Inflammatory Bowel Disease (IBD), it is well known that a strong unbalanced ratio among the genera of potentially protective bacteria and normal anaerobic bacteria is present. In particular, Bacteroides sp., Eubacterium sp., and Lactobacillus sp are significantly decreased [113]. All these evidences suggest that Spirulina may be useful to improve animal and human health changing the gut microbiota composition and promoting beneficial batcterial growth.

\section{Safety and Acceptability}

The Food and Drug Administration (FDA) has categorized Arthrospira products as "generally recognized as safe" (GRAS) for human consumption and the Dietary Supplements Information Expert Committee (DSI-EC) concluded that there is not a serious risk to health with consumption of Spirulina [114].

Reported side effects associated with Spirulina consumption are insomnia and gastric problems with uncertain or unlikely causality [114] and only few cases of severe side effects have been reported, including a case of rhabdomyolysis after the consumption of $3 \mathrm{~g} /$ day for 1 month [115]. Two cases of anaphylaxis caused by Spirulina tablets were reported $[116,117]$ of which one in a 17-year-old male who had a history of atopic dermatitis, asthma, allergic rhinitis, and a possible pollen-food syndrome (oral allergy symptoms to tomato and cucumber) [117]. Three cases of autoimmune-mediated skin damage were reported, of which one in a 82-year-old woman [118], whereas the other two cases were observed in subjects consuming Spirulina as ingredient of multicomponent-nutraceuticals (organic cayenne pepper, ethylsulfonylmethane, and the algae Aphanizomenon flos-aquae and Spirulina or Ginseng, Ginkgo biloba, and Spirulina) [119]. In this regard, it is well known that plant-food and herbal supplements could have adverse effects, such as hepatotoxicity and autoimmune hepatitis [120]. Besides, the two cases described by Lee and Werth [119] involved a 57-year-old man with known pemphigus vulgaris and a 45 -year-old woman with a history of hypertension, chronic migraines and fibromyalgia. Furthermore, a case report of hepatotoxicity involved a 52-year-old Japanese man who had a history of hypertension, hyperlipidemia and type 2 diabetes (T2D) and taking medications (amlodipine besilate, simvastatin, and acarbose) [121]. In this context, potential food-drug interactions have been hypothesized for Spirulina [122] and for phenolic phytochemicals [123-125]. Therefore, Spirulina should be ingested with caution in subjects with diseases, in particular in patients in treatment with substrates of cytochrome P450 enzymes, such as immunosuppressant, antihypertensive, and lipid lowering drugs [121125].

Although Spirulina can be considered safe in healthy subjects, sensory characteristics of a functional food are important in the consumer acceptance of the product.

Table 2 shows the studies that have investigated the overall acceptability of foods with Spirulina, including baby formulas, pomegranate juices, biscuits, snacks, pasta, ice creams, yogurt, and acidophilus milks [32, 36, 85-92]. The number of panelists ranged between 4 and 43 , and the point scale was different between studies (Table 2). Only a study on functional biscuits containing Spirulina or phycocyanin isolated from Spirulina reported similar levels of acceptability versus control [36]. In the other studies, both higher and lower levels of acceptability were reported (Table 2). The results were affected by the type of product, by the percentage of Spirulina and by the type of panelists.

Baby food formulas with added Spirulina had an overall acceptability scores in the range from 82.72 to 96.37 and the trained panelists assigned the high scores to products with Spirulina 5\% [32]. 
TABLE 2: Acceptability of Spirulina products.

\begin{tabular}{|c|c|c|c|}
\hline Products & Panelists $(n)$ (point scale, PS) & Acceptability & Ref. \\
\hline 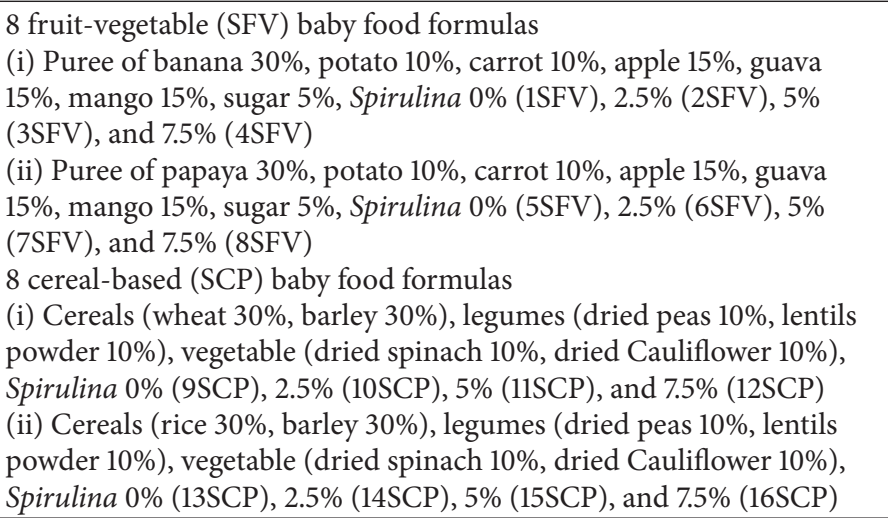 & Trained (12) (100 PS) & $\begin{array}{l}\text { Versus } 0 \%: \uparrow \text { (high } \\
\text { scores Spirulina 5\%: } \\
\text { 3SFV, 7SFV, 3SCP, and } \\
\text { 7SCP) }\end{array}$ & {$[32]$} \\
\hline $\begin{array}{l}\text { Pomegranate juice }(0 \%) \text { or pomegranate juice with Spirulina platensis } \\
(4 \%) \text { and Echinacea }(6 \%) \text { extracts sweetened by stevioside }(5 \%)\end{array}$ & Semi-trained (10) (10 PS) & Versus $0 \%: \uparrow$ & {$[85]$} \\
\hline $\begin{array}{l}\text { Biscuits }(0 \%) \text { or biscuits with Spirulina platensis } 0.3 \%, 0.6 \% \text {, and } 0.9 \% \\
\text { or phycocyanin extracts } 3.0 \%\end{array}$ & Untrained (20) (9 PS) & Versus $0 \%: \leftrightarrow$ & {$[36]$} \\
\hline $\begin{array}{l}\text { Snacks: corn flour (coating } 6 \% \text { cheese flavor }+19 \% \text { palm Olean oil) } \\
\text { with Spirulina } 0 \%, 2.5 \%, 5 \%, 7.5 \%, 10 \% \text {, and } 12.5 \%\end{array}$ & Trained (nr) (9 PS) & $\begin{array}{c}\text { Versus } 0 \%: 2.5 \% \uparrow, \\
5 \% \leftrightarrow, 7.5 \%, 10 \% \text {, and } \\
\quad 12.5 \% \downarrow\end{array}$ & {$[86]$} \\
\hline Pasta with Spirulina maxima $0 \%, 0.5 \%, 1.0 \%$, and $2.0 \%$ & Untrained (43) (5 PS) & Versus 0\%: $\uparrow$ & {$[87]$} \\
\hline Pasta with Spirulina platensis 5\%, $10 \%$, and $15 \%$ & Trained (7) (7 PS) & $\begin{array}{l}\text { Versus } 0 \%: \leftrightarrow 10 \% ; \downarrow 5 \% \\
\text { and } 15 \%\end{array}$ & {$[88]$} \\
\hline $\begin{array}{l}\text { Pasta } \\
\text { (i) Special wheat flour with } 0 \%, 5 \% \text {, and } 10 \% \text { of Spirulina platensis } \\
\text { (ii) Integral wheat flour with } 0 \%, 5 \% \text {, and } 10 \% \text { of Spirulina platensis }\end{array}$ & Consumers (nr) (9 PS) & $\begin{array}{l}\text { Versus } 0 \%: \leftrightarrow 5 \% ; \downarrow 10 \% \\
\text { (special wheat flour } \\
\text { versus integral wheat } \\
\text { flour: } \downarrow \text { ) }\end{array}$ & {$[89]$} \\
\hline $\begin{array}{l}\text { Ice cream } 0 \%, 0.075 \%, 0.15 \%, 0.23 \% \text {, and } 0.3 \% \text { of Spirulina to replace } \\
0 \%, 25 \%, 50 \%, 75 \% \text {, and } 100 \% \text { of stabilizer }\end{array}$ & Judges (4) (100 PS) & $\begin{array}{c}\text { Versus } 0 \%: 0.075 \% \leftrightarrow, \\
0.15 \% \uparrow, 0.23 \% \text {, and } \\
0.3 \% \downarrow\end{array}$ & {$[90]$} \\
\hline Yogurt with $0 \%, 0.1 \%, 0.2,0.3$, and $0.5 \%$ of Spirulina & Judges (4) (100 PS) & $\begin{array}{c}\text { versus } 0 \%: 0.1 \text { and } \\
0.5 \% \downarrow ; 0.2 \% \leftrightarrow ; 0.3 \% \uparrow\end{array}$ & {$[91]$} \\
\hline $\begin{array}{l}\text { (i) Plain yogurt (only yogurt starters) with } 0 \%, 0.5 \% \text {, and } 1 \% \text { of } \\
\text { Spirulina platensis } \\
\text { (ii) Probiotic yogurt (L. acidophilus }+ \text { yogurt starter bacteria) with } \\
0 \%, 0.5 \% \text {, and } 1 \% \text { of Spirulina platensis } \\
\text { (iii) Acidophilus milk (only L. acidophilus.) with } 0 \%, 0.5 \% \text {, and } 1 \% \\
\text { Spirulina platensis }\end{array}$ & Trained (5) (5 PS) & $\leftrightarrow$ versus $0 \% 0.5 \%>1 \%$ & {$[92]$} \\
\hline
\end{tabular}

No significant differences were noticed by semitrained panelists between the pomegranate juices and formulate pomegranate beverage with Spirulina (4\%) and Echinacea (6\%) extracts (sweetened by stevioside 5\%) in appearance, color, odors, and consistency, while the other parameters including taste and overall acceptability showed a significant decrease in the mean values of pomegranate juice compared to the fresh formulate pomegranate beverage [85].

Trained panelists gave a higher score to a snack with $2.5 \%$ of Spirulina, but the addition of $7.5 \%$ or more decreased the acceptability [86]. The percentage of Spirulina in pasta considered acceptable is different in trained and untrained panelists. In particular, pasta with a percentage of Spirulina maxima up to $2 \%$ was preferred by untrained panelists compared to control pasta [87], whereas the most preferable one by trained panelists [88] was the pasta enriched with 10\% Spirulina platensis. The latter was not acceptable for consumers [89] who considered less acceptable also pasta produced with integral wheat flour. The percentage of Spirulina that did not decrease the acceptability is lower for ice cream compared with supplemented pasta (Table 2). A panel of judges considered ice cream with $0.15 \%$ of Spirulina a superior product when compared to $0 \%$ and $0.075 \%$ ice creams, due to the light green (pistachio) color, but the intense green color decreased overall acceptability of the ice cream with $0.23 \%$ and $0.3 \%$ of Spirulina [90]. On the contrary, yogurt with Spirulina $0.3 \%$ had a higher score compared to $0 \%, 0.1 \%, 0.2$, and $0.5 \%$ of Spirulina [91]. Malik et al. [91] suggested that the lower score at $0.1 \%$ level when compared to control may be attributed to dull color and appearance and less acidic flavor which is 
essential for acceptability of yogurt, whereas the low acceptability of the $0.5 \%$ can be due to increased acidity and intense green color. It is well known that Spirulina causes decrease in $\mathrm{pH}$ of yogurts, due to its effect on Lactobacilli growth and viability [82, 126]. Guldas and Irkin [92], with trained panelists who did not assign excessive sour taste to acidophilic yogurt, reported that the $0.5 \%$ of Spirulina powder addition was more acceptable than $1 \%$, due to the slightly greenish color and algal flavor of the latter compared to the former. Therefore, different sensory expectations, experiences, knowledge, learning, and attitude to eat affect the overall acceptability $[127,128]$.

\section{From Nutritional Supplement to Antioxidant and Immunomodulating Functional Food in Humans}

Due to its high nutritional value, Spirulina has been used for treatment of anemia and malnutrition in undernourished children [28, 29, 129] and disease patients [29, 103, 130, 131]. Positive effects of Spirulina at doses ranging between $1 \mathrm{~g} /$ day [131] and $200 \mathrm{~g} /$ day [28] against anemia have been reported in children [28, 29, 129], runners [132], senior citizens [133], patients with pathologies such as nonalcoholic fatty liver disease (NAFLD) [130], T2D [131], or HIV-infected [29, 103]. Only two studies did not find improvement in Hemoglobin (Hb) levels after Spirulina supplementation. In the first study (Spirulina $6 \mathrm{~g} /$ day, 30 days), Hb was measured only in a subgroup of 5 subjects, probably not enough to reach statistical significance [101]. In the second study, both supplemented and control groups received also dietary products supplied by the World Food Program (WFP) and showed improvement of protidemia [104]. Besides in HIV-infected patients [29, $103]$ and undernourished children $[28,29]$ increases in body weight were reported, probably due to protein content. In agreement with this hypothesis, in HIV-infected antiretroviral-naive patients an increase in fat free mass (FFM) has been observed versus soya supplementation [103]. On the other hand, Spirulina did not affect body weight in subjects with dyslipidemia [134]. In this context, Spirulina reduced plasma lipids concentrations in many studies $[12,13,100$, $106,108,130,134-137]$. Accordingly, the results of a recent meta-analysis [11] of 7 Randomized Controlled Trials (RCT) showed a significant effect of supplementation with Spirulina in reducing plasma concentrations of total cholesterol $(-46.76 \mathrm{mg} / \mathrm{dL}, p<0.001)$, low density lipoprotein (LDL) cholesterol $(-41.32 \mathrm{mg} / \mathrm{dL}, p<0.001)$, and triglycerides $(-44.23 \mathrm{mg} / \mathrm{dL}, p<0.001)$ and elevating those of HDL cholesterol $(+6.06 \mathrm{mg} / \mathrm{dL}, p=0.001)$. In overweight subjects [13] and in T2D patients with dyslipidemia [106] the improvement in the lipid profile was accompanied by a reduction of blood pressure. Furthermore, some studies found also decreased levels of glucose or HOMA-IR after Spirulina supplementation in healthy volunteers [12], in subjects with NAFLD [130], T2D [138], and HIV-infected antiretroviral-naïve patients $[102,135]$.

Table 3 summarizes the 17 studies [29, 93-108] that investigated the effect of long term consumption (duration range: 7 days [96]-12 months [102]) of Spirulina or Spirulinaderived Immulina on markers of immune and redox status.

The majority of the studies had a longitudinal (uncontrolled) or parallel design (controlled or uncontrolled), and only two studies followed a crossover design. The number of participants in individual trials was extremely variable, ranging from 8 [100] to 169 [102], and characteristics of subjects varied between studies. In particular, healthy subjects, elderly, runners, children, patients with HIV infection, and T2D patients with allergic rhinitis or chronic obstructive pulmonary disease (COPD) were enrolled (Table 3 ).

Various biomarkers were used to monitor different aspects of redox and immune status in biological fluids and cells. Markers of redox status included total antioxidant status (TAS, $n=4)$, vitamin C (vit. C, $n=2)$, GSH $(n=2)$, antioxidant enzymes $(n=4)$ (e.g., SOD, CAT, and GPX), and markers of lipid peroxidation $(n=7)$ [e.g., MDA, thiobarbituric acid reactive substances (TBARS), and peroxides $(\mathrm{ROOH})$ ]. Markers of immune function included cytokines $(n=3)$, ex vivo cytokines' production by peripheral blood mononuclear cells (PBMC) $(n=3)$, lymphocytes' populations $(n=7)$, lymphocytes' proliferation $(n=1)$, and NK cytotoxic activity $(n=2)$.

Unchanged NK, NKT, and T cells were found after Spirulina consumption in healthy subjects [96]. Increases in T helper lymphocytes (CD4+ counts) were reported in HIVinfected patients (Table 3). In particular, the increase in CD4+ count was always accompanied by a decrease in the viral load [101-103]. This effect could be mediated by the antiviral activity against HIV of the natural sulfated polysaccharide (calcium spirulan), contained in Spirulina [139]. Accordingly, the increase in lymphocytes was observed in HIV-positive, but not in HIV-negative undernourished children [29]. Furthermore, Winter et al. [105] reported no effects on viral load with consequent progression of disease (e.g., decrease of CD4+ cells), in HIV patients, despite the increase in TAS. Also other three studies measured both redox and immune markers $[98,99,106]$.

A recent study in elderly found a lower increase in the IL-2/IL-6 ratio in obese compared to normal weight (NW) after Spirulina supplementation [98]. Furthermore, only in NW subjects an improvement of TAS and TBARS levels after treatment was observed [98]. Also gender differences were found in elderly after Spirulina consumption, with increase of IL- 2 and SOD in female and decrease of IL- 6 accompanied by increase in TAS in males [99]. The third study, conducted in T2D patients, found decreased MDA levels that were associated with decrease of IL- 6 only in patients with dyslipidaemia [106]. Therefore, the concerted modulation of redox and inflammatory status by Spirulina in humans requires more studies.

On the other hand, improvement of at least one marker of redox status (decrease in markers of peroxidation and/or increase in antioxidant enzymes, TAS, GSH, or vitamin C) was reported in healthy subjects ( $7.5 \mathrm{~g} /$ day, 3 weeks) [95], elderly (8 g/day, 12 and 16 weeks) [98, 99], runners (4 g/day, 2 weeks) [100], COPD (1 $\mathrm{g}$ and $2 \mathrm{~g} /$ day, 60 days) [108], and T2D (8 g/day, 12 weeks) [106] patients. Only Shyam et al. [97] reported decreased GSH and unchanged MDA, TAS, vitamin 
TABLE 3: Human intervention studies measuring markers of immune function or redox status after Spirulina supplementation.

\begin{tabular}{|c|c|c|c|c|}
\hline Subjects $(n)$ & Study design and treatment & Markers of immune function & $\begin{array}{l}\text { Markers of redox } \\
\text { status }\end{array}$ & Ref. \\
\hline Healthy (11) & $\begin{array}{c}\text { Longitudinal } \\
\text { Spirulina-derived Immulina } 400 \mathrm{mg} / \mathrm{day}, 56 \\
\text { days }\end{array}$ & $\begin{array}{c}\text { Proliferation } \\
\downarrow \text { CA-induced CD19+ (day 56) } \\
\uparrow \text { CA-induced CD19+ (3-8 days), CD4+ } \\
\text { (3-56 days) } \\
\uparrow \text { TT-induced CD4+ (3-8 days) } \\
\text { Cytokines' production } \\
\downarrow \text { TT- induced TNF- } \alpha \text {, IFN- } \gamma \text {, IL-5 (day } \\
56 \text { ) } \\
\downarrow \text { CA and TT- induced IL-4 (day 3) } \\
\leftrightarrow \text { TT-induced IL-2, IL-12, IL-10 } \\
\uparrow \text { CA-induced TNF- } \alpha \text { (3-8 days), IL-2 } \\
\text { (day 3 and 56), } \\
\text { IFN- } \gamma \text { (day 3), IL-6 (3-14 days), IL-5 (3-8 } \\
\text { days) } \\
\uparrow \text { TT-induced TNF- } \alpha \text { (3-8 days), IFN- } \gamma \\
\text { (3-14 days), } \\
\text { IL-6 (3-8 days), IL-5 (3-8 days) }\end{array}$ & & [93] \\
\hline Healthy (12) & $\begin{array}{l}\text { Longitudinal } \\
50 \mathrm{ml} \text { hot water extract of Spirulina platensis } \\
\text { extract, } 8 \text { weeks }\end{array}$ & $\begin{array}{c}\uparrow \text { NK cell cytotoxic activity } \\
\text { Cytokines' production } \\
\leftrightarrow \text { Con A-induced IL-12 } \\
\uparrow \text { BCG-CWS-induced IL-12, } \\
\uparrow \text { IL-12 and IL12/IL18-induced IFN- } \gamma\end{array}$ & & {$[94]$} \\
\hline Healthy (16) & $\begin{array}{l}\text { Parallel (versus soya proteins) } \\
\text { Spirulina platensis or soya } 7.5 \mathrm{~g} / \text { day, } 3 \text { weeks } \\
\text { (after exercise) }\end{array}$ & & $\begin{array}{l}\uparrow \mathrm{SOD}, \mathrm{GPX} \\
\downarrow \mathrm{MDA}\end{array}$ & {$[95]$} \\
\hline Healthy (20) & $\begin{array}{l}\text { Crossover (placebo controlled) } \\
\text { Spirulina-derived Immulina } 0.2 \mathrm{~g} \text { and } 0.4 \mathrm{~g} / \text { day, } \\
7 \text { days }\end{array}$ & $\begin{array}{l}\uparrow \text { NK cell cytotoxic activity } \\
\leftrightarrow \text { NK, NKT, T cells }\end{array}$ & & {$[96]$} \\
\hline Healthy (30) & $\begin{array}{l}\text { Parallel (placebo controlled) } \\
\text { Spirulina maxima } 1 \mathrm{~g} / \text { day, } 30 \text { days }\end{array}$ & & $\begin{array}{c}\leftrightarrow \text { MDA, TAS, vit. } \\
\text { C, SOD } \\
\downarrow \text { GSH }\end{array}$ & {$[97]$} \\
\hline $\begin{array}{l}\text { Elderly } \\
\text { NW (45) } \\
\text { Obese (33) } \\
\end{array}$ & $\begin{array}{l}\text { Parallel (placebo controlled) } \\
\text { Spirulina } 8 \text { g/day, } 12 \text { weeks }\end{array}$ & $\begin{array}{c}\uparrow \text { IL-2 (NW } 54.1 \% \text {, obese } 33 \% \text { ) } \\
\downarrow \text { IL-6 (NW 20\%, obese } 14.6 \% \text { ) } \\
\leftrightarrow \text { TNF- } \alpha\end{array}$ & $\begin{array}{c}\uparrow \text { TAS (only NW) } \\
\downarrow \text { TBARS (only NW) }\end{array}$ & {$[98]$} \\
\hline Elderly (78) & $\begin{array}{l}\text { Parallel (placebo controlled) } \\
\text { freeze-dried Spirulina } 8 \mathrm{~g} / \text { day, } 16 \text { weeks }\end{array}$ & $\begin{array}{c}\uparrow \text { IL-2 (female) } \\
\downarrow \text { IL-6 (male) }\end{array}$ & $\begin{array}{l}\uparrow \text { SOD (female), } \\
\text { TAS (male) } \\
\leftrightarrow \text { GPX, TBARS }\end{array}$ & {$[99]$} \\
\hline Runners (8) & $\begin{array}{c}\text { Longitudinal } \\
\text { Spirulina maxima capsules } 4 \mathrm{~g} / \text { day }+ \\
200 \mathrm{ml} / \text { day antioxidants drink } \mathrm{k}^{\dagger}, 2 \text { weeks }\end{array}$ & & $\downarrow \mathrm{MDA}$ & {$[100]$} \\
\hline $\mathrm{HIV}+(84)$ & $\begin{array}{l}\text { Parallel (versus untreated) } \\
\text { Spirulina platensis } 20 \mathrm{~g} / \text { day, } 8 \text { weeks }\end{array}$ & $\uparrow$ lymphocytes & & {$[29]$} \\
\hline $\mathrm{HIV}+(11)$ & $\begin{array}{l}\text { Parallel (uncontrolled) } \\
\text { Spirulina platensis capsules } 6 \mathrm{~g} / \text { day, } 3 \text { months } \\
\text { Undaria } 5 \mathrm{~g} / \text { day, } 3 \text { months } \\
\text { Spirulina capsules } 3 \mathrm{~g} / \text { day + Undaria } 2.5 \mathrm{~g} / \text { day, } \\
3 \text { months }\end{array}$ & $\begin{array}{c}\uparrow \mathrm{CD} 4(n=6) \\
\downarrow \text { viral load }(n=6)\end{array}$ & & {$[101]$} \\
\hline $\mathrm{HIV}+(169)$ & $\begin{array}{c}\text { Parallel (placebo controlled) } \\
\text { Spirulina platensis powder } 10 \text { g/day, } 12 \text { months }\end{array}$ & $\begin{array}{c}\uparrow \mathrm{CD} 4 \\
\downarrow \text { viral load } \\
\end{array}$ & & {$[102]$} \\
\hline $\mathrm{HIV}+(52)$ & $\begin{array}{c}\text { Parallel (uncontrolled) } \\
\text { proteins } 1.5 \mathrm{~g} / \mathrm{kg} \text { body weight }(25 \% \text { Spirulina } \\
\text { platensis or soya) }\end{array}$ & $\begin{array}{c}\uparrow \mathrm{CD} 4 \text { (both groups, } \uparrow \text { versus soya) } \\
\downarrow \text { viral load (both groups and } \downarrow \text { versus } \\
\text { soya) }\end{array}$ & & {$[103]$} \\
\hline
\end{tabular}


TABLE 3: Continued.

\begin{tabular}{|c|c|c|c|c|}
\hline Subjects $(n)$ & Study design and treatment & Markers of immune function & $\begin{array}{c}\text { Markers of redox } \\
\text { status }\end{array}$ & Ref. \\
\hline $\mathrm{HIV}+(160)$ & $\begin{array}{l}\text { Parallel (placebo controlled) } \\
\text { Spirulina } 10 \text { g/day, } 6 \text { months }\end{array}$ & $\uparrow C D 4$ (both groups) & & {$[104]$} \\
\hline $\mathrm{HIV}+(73)$ & $\begin{array}{l}\text { Parallel (placebo controlled) } \\
\text { Spirulina platensis powder } 5 \mathrm{~g} / \text { day, } 3 \text { months }\end{array}$ & $\begin{array}{c}\downarrow \downarrow \text { CD4 (both groups) } \\
\leftrightarrow \text { viral load, CD38 expression on the } \\
\text { CD8 }\end{array}$ & $\uparrow \mathrm{TAS}$ & {$[105]$} \\
\hline T2D (37) & $\begin{array}{l}\text { Parallel (placebo controlled) } \\
\text { freeze-dried Spirulina } 8 \mathrm{~g} / \text { day, } 12 \text { weeks }\end{array}$ & $\begin{array}{l}\downarrow \text { IL-6 (only in patients with } \\
\text { dyslipidemia) } \\
\leftrightarrow \text { TNF- } \alpha\end{array}$ & $\downarrow \mathrm{MDA}$ & {$[106]$} \\
\hline $\begin{array}{l}\text { Allergic rhinitis } \\
(36)\end{array}$ & $\begin{array}{l}\text { Crossover (placebo controlled) } \\
\text { Spirulina capsules } 1 \mathrm{~g} \text { and } 2 \mathrm{~g} / \text { day, } 12 \text { weeks }\end{array}$ & $\begin{array}{c}\text { Cytokines' production } \\
\downarrow \text { PHA-induced IL-4 (only } 2 \text { g/day) } \\
\leftrightarrow \text { PHA-induced IFN- } \gamma \text {, IL-2 } \\
\end{array}$ & & {$[107]$} \\
\hline COPD (30) & $\begin{array}{l}\text { Parallel (uncontrolled: } 2 \text { doses) } \\
\text { Spirulina capsules } 1 \mathrm{~g} \text { and } 2 \mathrm{~g} \text { /day, } 60 \text { days }\end{array}$ & & $\begin{array}{c}\uparrow \text { CAT (only } \\
2 \text { g/day), SOD, GST, } \\
\text { GSH, vit. C } \\
\downarrow \text { MDA, ROOH }\end{array}$ & [108] \\
\hline
\end{tabular}

$n=$ numbers; $^{\dagger}$ antioxidants drink containing $\beta$ Carotene $7600 \mathrm{mcg}$, vitamin A $400 \mathrm{IU}$, vitamin E $80 \mathrm{IU}$, vitamin C- $320 \mathrm{mg}$, zinc- $2.7 \mathrm{mg}$, and selenium$40 \mathrm{mcg} ;{ }^{*}$ both groups received also dietary products supplied by the World Food Program (WFP); BCG-CWS: cell wall skeleton of Mycobacterium bovis Bacillus Calmette-Guérin; CA: Candidaalbicans; CAT: catalase; Con A: concanavalin A; COPD: chronic obstructive pulmonary disease; GSH: glutathione; IL: interleukin; MDA: malondialdehyde; PHA: phytohemagglutinin; ROOH: lipid hydroperoxides; SOD: superoxide dismutase; T2D: type 2 diabetes; TAS: total antioxidant status; TT: tetanus toxoid.

C, and SOD in healthy subjects after Spirulina $(1 \mathrm{~g} /$ day, 30 days).

Concerning the ex vivo markers of immune function, NK cytotoxic activity increased after both 7 days [96] and 8 weeks [94] of Spirulina or Spirulina-derived Immulina supplementation, whereas data on proliferation of lymphocytes and cytokines' production varied with the stimulus used (BCG-CWS: cell wall skeleton of Mycobacterium bovis Bacillus Calmette-Guérin; CA: Candida albicans; Con A: concanavalin A; PHA: phytohemagglutinin; or TT: tetanus toxoid) and the duration of supplementation (Table 3), also in the same study [93]. In particular, after the Spirulinaderived Immulina $400 \mathrm{mg} /$ day for 56 days, a significant correlation between age and the increase in TT-induced CD4+ proliferation was found, while significant correlations were not found with respect to CA response. On the other hand, no effect was observed on TT-induced proliferation of CD19+, whereas the CA-induced CD19+ proliferation was increased after 3-8 days but decreased at day 56. Also the effect on the production of cytokines was temporary. The CAand TT-induced production of IL-5 a Th2-related cytokine was increased at the beginning of the supplementation (38 days) but was inhibited at 56 days. On the contrary, the CA- and TT-induced production of IL-4 was decreased at day 3 and no effect was observed on IL-10 response during all the supplementation period. Concerning Thl cytokines, after 3, 8, and/or 14 days of consumption a significant increase was observed of the CA- and/or TT-induced production of TNF- $\alpha$ (3-8 days, CA and TT), IFN- $\gamma$ (day 3 CA, 3-14 days TT), and IL-2 (only CA day 3 and day 56), whereas at day 56 the TT-induced productions of TNF- $\alpha$ and IFN$\gamma$ were decreased. Although both Th1 and Th2 improvements were temporary, the increase in IFN- $\gamma$ could account for the increased NK activity observed in other studies with Spirulina or Spirulina-derived Immulina $[94,96]$.

Overall, Spirulina seems to affect more innate immunity than adaptative immunity, but the immunomodulating activity of Spirulina in humans requires further investigations.

Furthermore, in the majority of the studies the effect of Spirulina (Arthrospira) platensis or a Spirulina not specified species has been investigated and only in two studies Spirulina maxima has been used (Table 3 ). Therefore, more studies are needed in order to evaluate the possible speciespecific effects in humans.

\section{Conclusion}

The concerted modulation of antioxidant and inflammatory responses (by Nrf2 and NF-kB pathways), suggested by in vitro and animal studies (Table 1), requires more confirmation in humans (Table 3). It has been suggested that the temporary priming effect on the responses of peripheral Th1, Th2, and B cells to antigenic stimuli could be related to a proinflammatory effect of Immulina [93]. However, the effects on cytokines and on lymphocytes' proliferation are contrasting, depending on age, gender, and body weight differences. In this context, ageing [140], obesity [141, 142], and metabolic syndrome [142] are associated not only to chronic low grade inflammation, but also to immune impairment (recurrent infection and low vaccine efficacy). Therefore the increased immune response to antigenic stimuli could be protective in elderly [93].

On the other hand, Spirulina has hypolipidemic, hypoglycemic, and antihypertensive properties, useful in the prevention of the metabolic syndrome [18]. In this context, 
the alteration of gut microbiota is common in elderly [140], obese [141], and subjects with the metabolic syndrome [18].

From that, the microbial-modulating activities of Spirulina (reported in vitro and in animal models, Figure 1) suggest that the association Spirulina and probiotics could represent a new synbiotic, maintaining and/or restoring the homeostasis at level of gut microbiota. Human intervention studies are required for confirmation of this hypothesis.

Furthermore, Spirulina improves oxidative stress markers and NK activity in healthy subjects and CD4+ count in HIV+ patients.

However, among bioactive molecules from Spirulina (Table 1) only Immulina has been tested in humans (Table 3 ). Therefore the role of bioactive molecules from Spirulina for human applications requires further studies. Moreover, despite the fact that Spirulina might represent a functional food with potential beneficial effects on human health, the human interventions used supplements (Table 3). Although the tested doses (1-20 g/day) in these studies (Table 3) were not greater than the maximum acceptable percentage (10\%) of Spirulina in functional foods (Table 2), no data are available on the efficacy of Spirulina containing foods. Therefore, the healthy effect of food containing Spirulina should be further evaluated.

Besides, previous studies indicate that some antioxidant and immunological markers are sensitive to stimuli that affect the mood of the individual. In particular, the salivary TAC increased 30 minutes after the vision of a comical video [143] and pleasant emotions increase the salivary IgA and cortisol [144]. In this context different species of Spirulina, possibly having different biological effects, showed different acceptability $[87,88]$. Therefore, the study of the relationship between liking and markers of antioxidant and immune status should be considered in humans studies.

\section{Competing Interests}

The authors declare that there is no conflict of interests regarding the publication of this paper.

\section{Acknowledgments}

The authors thank Claudio Andrew Gobbi for English review of the manuscript.

\section{References}

[1] A. A. Al-Homaidan, J. A. Alabdullatif, A. A. Al-Hazzani, A. A. Al-Ghanayem, and A. F. Alabbad, "Adsorptive removal of cadmium ions by Spirulina platensis dry biomass," Saudi Journal of Biological Sciences, vol. 22, no. 6, pp. 795-800, 2015.

[2] A. Çelekli, M. Yavuzatmaca, and H. Bozkurt, "An eco-friendly process: predictive modelling of copper adsorption from aqueous solution on Spirulina platensis," Journal of Hazardous Materials, vol. 173, no. 1-3, pp. 123-129, 2010.

[3] A. Cain, R. Vannela, and L. K. Woo, "Cyanobacteria as a biosorbent for mercuric ion," Bioresource Technology, vol. 99, no. 14, pp. 6578-6586, 2008.
[4] A. Şeker, T. Shahwan, A. E. Eroğlu, S. Yilmaz, Z. Demirel, and M. C. Dalay, "Equilibrium, thermodynamic and kinetic studies for the biosorption of aqueous lead(II), cadmium(II) and nickel(II) ions on Spirulina platensis," Journal of Hazardous Materials, vol. 154, no. 1-3, pp. 973-980, 2008.

[5] L. Fang, C. Zhou, P. Cai et al., "Binding characteristics of copper and cadmium by cyanobacterium Spirulina platensis," Journal of Hazardous Materials, vol. 190, no. 1-3, pp. 810-815, 2011.

[6] G. L. Dotto, J. O. Gonçalves, T. R. S. Cadaval, and L. A. A. Pinto, "Biosorption of phenol onto bionanoparticles from Spirulinasp. LEB 18," Journal of Colloid and Interface Science, vol. 407, pp. 450-456, 2013.

[7] S. K. Singh, A. Rahman, K. Dixit, A. Nath, and S. Sundaram, "Evaluation of promising algal strains for sustainable exploitation coupled with CO2 fixation," Environmental Technology, vol. 37, no. 5, pp. 613-622, 2016.

[8] J. Coppens, R. Lindeboom, M. Muys et al., "Nitrification and microalgae cultivation for two-stage biological nutrient valorization from source separated urine," Bioresource Technology, vol. 211, pp. 41-50, 2016.

[9] R. R. Siva Kiran, G. M. Madhu, and S. V. Satyanarayana, "Spirulina in combating Protein Energy Malnutrition (PEM) and Protein Energy Wasting (PEW) - a review," Journal of Nutrition Research, vol. 3, no. 1, pp. 62-79, 2015.

[10] B. W. B. Holman and A. E. O. Malau-Aduli, "Spirulina as a livestock supplement and animal feed," Journal of Animal Physiology and Animal Nutrition, vol. 97, no. 4, pp. 615-623, 2013.

[11] M.-C. Serban, A. Sahebkar, S. Dragan et al., "A systematic review and meta-analysis of the impact of Spirulina supplementation on plasma lipid concentrations," Clinical Nutrition, vol. 35, no. 4, pp. 842-851, 2016.

[12] M. Iyer Uma, A. Sophia, and V. Mani Uliyar, "Glycemic and lipemic responses of selected Spirulina supplemented ricebased recipes in normal subjects," International Journal of Diabetes in Developing Countries, vol. 19, pp. 17-22, 1999.

[13] P. V. Torres-Duran, A. Ferreira-Hermosillo, and M. A. JuarezOropeza, "Antihyperlipemic and antihypertensive effects of Spirulina maxima in an open sample of mexican population: a preliminary report," Lipids in Health and Disease, vol. 6, article no. 33, 2007.

[14] K. Iwata, T. Inayama, and T. Kato, "Effects of spirulina platensis on plasma lipoprotein lipase activity in fructose-induced hyperlipidemic rats," Journal of Nutritional Science and Vitaminology, vol. 36, no. 2, pp. 165-171, 1990.

[15] P. Muthuraman, R. Senthilkumar, and K. Srikumar, "Alterations in beta-islets of Langerhans in alloxan-induced diabetic rats by marine Spirulina platensis," Journal of Enzyme Inhibition and Medicinal Chemistry, vol. 24, no. 6, pp. 1253-1256, 2009.

[16] Y. Ou, L. Lin, X. Yang, Q. Pan, and X. Cheng, "Antidiabetic potential of phycocyanin: effects on KKAy mice," Pharmaceutical Biology, vol. 51, no. 5, pp. 539-544, 2013.

[17] J. Lu, D.-F. Ren, Y.-L. Xue, Y. Sawano, T. Miyakawa, and M. Tanokura, "Isolation of an antihypertensive peptide from alcalase digest of Spirulina platensis," Journal of Agricultural and Food Chemistry, vol. 58, no. 12, pp. 7166-7171, 2010.

[18] I. Peluso, L. Romanelli, and M. Palmery, "Interactions between prebiotics, probiotics, polyunsaturated fatty acids and polyphenols: diet or supplementation for metabolic syndrome prevention?" International Journal of Food Sciences and Nutrition, vol. 65, no. 3, pp. 259-267, 2014. 
[19] M. M. El-Sheekh, S. Daboo, M. A. Swelim, and S. Mohamed, "Production and characterization of antimicrobial active substance from Spirulina platensis," Iranian Journal of Microbiology, vol. 6, no. 2, pp. 112-119, 2014.

[20] G. Ozdemir, N. U. Karabay, M. C. Dalay, and B. Pazarbasi, “Antibacterial activity of volatile component and various extracts of Spirulina platensis," Phytotherapy Research, vol. 18, no. 9, pp. 754-757, 2004.

[21] P. Kaushik and A. Chauhan, "In vitro antibacterial activity of laboratory grown culture of Spirulina platensis," Indian Journal of Microbiology, vol. 48, no. 3, pp. 348-352, 2008.

[22] J. L. Parada, G. Zulpa de Caire, M. C. Zulpa de Mulé, and M. M. Storni de Cano, "Lactic acid bacteria growth promoters from Spirulina platensis," International Journal of Food Microbiology, vol. 45, no. 3, pp. 225-228, 1998.

[23] L. Varga, J. Szigeti, R. Kovács, T. Földes, and S. Buti, "Influence of a Spirulina platensis biomass on the microflora of fermented ABT milks during storage (R1)," Journal of Dairy Science, vol. 85, no. 5, pp. 1031-1038, 2002.

[24] G. Mocanu, E. Botez, O. V. Nistor, D. G. Andronoiu, and G. Vlăsceanu, "Influence of Spirulina platensis biomass over some starter culture of lactic bacteria," Journal of Agroalimentary Processes and Technologies, vol. 19, no. 4, pp. 474-479, 2013.

[25] L. Machu, L. Misurcova, J. V. Ambrozova et al., "Phenolic content and antioxidant capacity in algal food products," Molecules, vol. 20, no. 1, pp. 1118-1133, 2015.

[26] G. S. Jensen, V. L. Attridge, J. L. Beaman, J. Guthrie, A. Ehmann, and K. F. Benson, "Antioxidant and anti-inflammatory properties of an aqueous cyanophyta extract derived from arthrospira platensis: contribution to bioactivities by the non-phycocyanin aqueous fraction," Journal of Medicinal Food, vol. 18, no. 5, pp. 535-541, 2015.

[27] J. Riss, K. Décordé, T. Sutra et al., "Phycobiliprotein Cphycocyanin from Spirulina platensis is powerfully responsible for reducing oxidative stress and NADPH oxidase expression induced by an atherogenic diet in hamsters," Journal of Agricultural and Food Chemistry, vol. 55, no. 19, pp. 7962-7967, 2007.

[28] J. Simpore, F. Kabore, F. Zongo et al., "Nutrition rehabilitation of undernourished children utilizing Spiruline and Misola," Nutrition Journal, vol. 5, article 3, 2006.

[29] J. Simpore, F. Zongo, F. Kabore et al., "Nutrition rehabilitation of HIV-infected and HIV-negative undernourished children utilizing spirulina," Annals of Nutrition and Metabolism, vol. 49, no. 6, pp. 373-380, 2005.

[30] S. Bensehaila, A. Doumandji, L. Boutekrabt et al., "The nutritional quality of Spirulina platensis of Tamenrasset, Algeria," African Journal of Biotechnology, vol. 14, no. 9, pp. 1649-1654, 2015.

[31] J. V. Ambrozova, L. Misurcova, R. Vicha et al., "Influence of extractive solvents on lipid and fatty acids content of edible freshwater algal and seaweed products, the green microalga Chlorella kessleri and the cyanobacterium Spirulina platensis," Molecules, vol. 19, no. 2, pp. 2344-2360, 2014.

[32] A. M. Sharoba, "Nutritional value of spirulina and its use in the preparation of some complementary baby food formulas," Journal of Food and Dairy Sciences, Mansoura University, no. 8, pp. 517-538, 2014.

[33] A. Kumudha, S. S. Kumar, M. S. Thakur, G. A. Ravishankar, and R. Sarada, "Purification, identification, and characterization of methylcobalamin from Spirulina platensis," Journal of Agricultural and Food Chemistry, vol. 58, no. 18, pp. 9925-9930, 2010.
[34] D. Banji, O. J. F. Banji, N. G. Pratusha, and A. R. Annamalai, "Investigation on the role of Spirulina platensis in ameliorating behavioural changes, thyroid dysfunction and oxidative stress in offspring of pregnant rats exposed to fluoride," Food Chemistry, vol. 140, no. 1-2, pp. 321-331, 2013.

[35] D. J. M. Gómez-Coronado, E. Ibañez, F. J. Rupérez, and C. Barbas, "Tocopherol measurement in edible products of vegetable origin," Journal of Chromatography A, vol. 1054, no. 1-2, pp. 227-233, 2004.

[36] H. H. A. El Baky, G. S. El Baroty, and E. A. Ibrahem, "Functional characters evaluation of biscuits sublimated with pure phycocyanin isolated from Spirulinaand Spirulina biomass," Nutricion Hospitalaria, vol. 32, no. 1, pp. 231-241, 2015.

[37] A. Ranga Rao, R. L. Raghunath Reddy, V. Baskaran, R. Sarada, and G. A. Ravishankar, "Characterization of microalgal carotenoids by mass spectrometry and their bioavailability and antioxidant properties elucidated in rat model," Journal of Agricultural and Food Chemistry, vol. 58, no. 15, pp. 8553-8559, 2010.

[38] M. M. Abdel-Daim, "Pharmacodynamic interaction of Spirulina platensis with erythromycin in Egyptian Baladi bucks (Capra hircus)," Small Ruminant Research, vol. 120, no. 2-3, pp. 234-241, 2014.

[39] M. Abdel-Daim, B. E. El-Bialy, H. G. A. Rahman, A. M. Radi, H. A. Hefny, and A. M. Hassan, "Antagonistic effects of Spirulina platensis against sub-acute deltamethrin toxicity in mice: biochemical and histopathological studies," Biomedicine and Pharmacotherapy, vol. 77, pp. 79-85, 2016.

[40] R. A. Kepekçi, S. Polat, A. Çelik, N. Bayat, and S. D. Saygideger, "Protective effect of Spirulina platensis enriched in phenolic compounds against hepatotoxicity induced by $\mathrm{CCl}_{4}$," Food Chemistry, vol. 141, no. 3, pp. 1972-1979, 2013.

[41] S. A. E. Bashandy, S. A. El Awdan, H. Ebaid, and I. M. Alhazza, "Antioxidant potential of Spirulina platensis mitigates oxidative stress and reprotoxicity induced by sodium arsenite in male rats," Oxidative Medicine and Cellular Longevity, vol. 2016, Article ID 7174351, 8 pages, 2016.

[42] G. E. El-Desoky, S. A. Bashandy, I. M. Alhazza, Z. A. AlOthman, M. A. M. Aboul-Soud, and K. Yusuf, "Improvement of mercuric chloride-induced testis injuries and sperm quality deteriorations by Spirulina platensis in rats," PLOS ONE, vol. 8, no. 3, Article ID e59177, 2013.

[43] M. O. Elshazly, S. S. Abd El-Rahman, A. M. Morgan, and M. E. $\mathrm{Ali}$, "The remedial efficacy of spirulina platensis versus chromium-induced nephrotoxicity in male sprague-dawley rats," PLoS ONE, vol. 10, no. 6, Article ID 0126780, 2015.

[44] A. Karadeniz, M. Cemek, and N. Simsek, "The effects of Panax ginseng and Spirulina platensis on hepatotoxicity induced by cadmium in rats," Ecotoxicology and Environmental Safety, vol. 72, no. 1, pp. 231-235, 2009.

[45] M. M. Abdel-Daim, S. M. M. Abuzead, and S. M. Halawa, "Protective role of Spirulina platensis against acute deltamethrininduced toxicity in rats," PLOS ONE, vol. 8, no. 9, Article ID e72991, 2013.

[46] A. E. Ibrahim and M. M. Abdel-Daim, "Modulating effects of spirulina platensis against tilmicosin-induced cardiotoxicity in mice," Cell Journal, vol. 17, no. 1, pp. 137-144, 2015.

[47] A. Karadeniz, A. Yildirim, N. Simsek, Y. Kalkan, and F. Celebi, "Spirulina platensis protects against gentamicin-induced nephrotoxicity in rats," Phytotherapy Research, vol. 22, no. 11, pp. 1506-1510, 2008.

[48] M. M. Abdel-Daim, S. M. Farouk, F. F. Madkour, and S. S. Azab, "Anti-inflammatory and immunomodulatory effects of 
Spirulina platensis in comparison to Dunaliella salina in acetic acid-induced rat experimental colitis," Immunopharmacology and Immunotoxicology, vol. 37, no. 2, pp. 126-139, 2015.

[49] E. A. I. Ali, B. M. Barakat, and R. Hassan, "Antioxidant and angiostatic effect of spirulina platensis suspension in complete Freund's adjuvant-induced arthritis in rats," PLoS ONE, vol. 10, no. 4, Article ID e0121523, 2015.

[50] N. Kumar, S. Singh, N. Patro, and I. Patro, "Evaluation of protective efficacy of Spirulina platensis against collagen-induced arthritis in rats," Inflammopharmacology, vol. 17, no. 3, pp. 181190, 2009.

[51] R. Hu, C. L.-L. Saw, R. Yu, and A.-N. T. Kong, "Regulation of NF-E2-related factor 2 signaling for cancer chemoprevention: antioxidant coupled with antiinflammatory," Antioxidants and Redox Signaling, vol. 13, no. 11, pp. 1679-1698, 2010.

[52] Z.-Y. Su, L. Shu, T. O. Khor, J. H. Lee, F. Fuentes, and A.-N. T. Kong, "A perspective on dietary phytochemicals and cancer chemoprevention: oxidative stress, Nrf2, and epigenomics," Topics in Current Chemistry, vol. 329, pp. 133-162, 2013.

[53] S. Upadhyay and M. Dixit, "Role of polyphenols and other phytochemicals on molecular signaling," Oxidative Medicine and Cellular Longevity, vol. 2015, Article ID 504253, 15 pages, 2015.

[54] M. K. Saini and S. N. Sanyal, "Cell cycle regulation and apoptotic cell death in experimental colon carcinogenesis: intervening with cyclooxygenase-2 inhibitors," Nutrition and Cancer, vol. 67, no. 4, pp. 620-636, 2015.

[55] Y. Gao, C. Liu, G. Wan, X. Wang, X. Cheng, and Y. Ou, "Phycocyanin prevents methylglyoxal-induced mitochondrial-dependent apoptosis in INS-1 cells by Nrf2," Food and Function, vol. 7, no. 2, pp. 1129-1137, 2016.

[56] V. B. Bhat and K. M. Madyastha, "Scavenging of peroxynitrite by phycocyanin and phycocyanobilin from Spirulina platensis: protection against oxidative damage to DNA," Biochemical and Biophysical Research Communications, vol. 285, no. 2, pp. 262266, 2001.

[57] V. B. Bhat and K. M. Madyastha, "C-phycocyanin: a potent peroxyl radical scavenger in vivo and in vitro," Biochemical and Biophysical Research Communications, vol. 275, no. 1, pp. 20-25, 2000.

[58] P. Bermejo-Bescós, E. Piñero-Estrada, and Á. M. Villar del Fresno, "Neuroprotection by Spirulina platensis protean extract and phycocyanin against iron-induced toxicity in SH-SY5Y neuroblastoma cells," Toxicology in Vitro, vol. 22, no. 6, pp. 14961502, 2008.

[59] T. Chen and Y.-S. Wong, "In vitro antioxidant and antiproliferative activities of selenium-containing phycocyanin from selenium-enriched Spirulina platensis," Journal of Agricultural and Food Chemistry, vol. 56, no. 12, pp. 4352-4358, 2008.

[60] R. Koníčková, K. Vaňková, J. Vaníková et al., “Anti-cancer effects of blue-green alga Spirulina platensis, a natural source of bilirubin-like tetrapyrrolic compounds," Annals of Hepatology, vol. 13, no. 2, pp. 273-283, 2014.

[61] H. Zhang, T. Chen, J. Jiang, Y.-S. Wong, F. Yang, and W. Zheng, "Selenium-containing allophycocyanin purified from selenium-enriched Spirulina platensis attenuates AAPH-induced oxidative stress in human erythrocytes through inhibition of ROS generation," Journal of Agricultural and Food Chemistry, vol. 59, no. 16, pp. 8683-8690, 2011.

[62] C. M. Reddy, V. B. Bhat, G. Kiranmai, M. N. Reddy, P. Reddanna, and K. M. Madyastha, "Selective inhibition of cyclooxygenase2 by C-phycocyanin, a biliprotein from Spirulina platensis,"
Biochemical and Biophysical Research Communications, vol. 277, no. 3, pp. 599-603, 2000.

[63] J.-C. Chen, K. S. Liu, T.-J. Yang, J.-H. Hwang, Y.-C. Chan, and I.-T. Lee, "Spirulina and C-phycocyanin reduce cytotoxicity and inflammation-related genes expression of microglial cells," Nutritional Neuroscience, vol. 15, no. 6, pp. 252-256, 2012.

[64] C.-M. Shih, S.-N. Cheng, C.-S. Wong, Y.-L. Kuo, and T.-C. Chou, "Antiinflammatory and antihyperalgesic activity of Cphycocyanin," Anesthesia and Analgesia, vol. 108, no. 4, pp. 1303-1310, 2009.

[65] J.-H. Hwang, J.-C. Chen, and Y.-C. Chan, "Effects of C-phycocyanin and Spirulina on salicylate-induced tinnitus, expression of NMDA receptor and inflammatory genes," PLoS ONE, vol. 8, no. 3, Article ID e58215, 2013.

[66] S. M. Farooq, D. Asokan, R. Sakthivel, P. Kalaiselvi, and P. Varalakshmi, "Salubrious effect of C-phycocyanin against oxalatemediated renal cell injury," Clinica Chimica Acta, vol. 348, no. 1-2, pp. 199-205, 2004.

[67] C. S. Ku, T. X. Pham, Y. Park et al., "Edible blue-green algae reduce the production of pro-inflammatory cytokines by inhibiting NF- $\kappa$ B pathway in macrophages and splenocytes," Biochimica et Biophysica Acta-General Subjects, vol. 1830, no. 4, pp. 2981-2988, 2013.

[68] D. H. Kim, M. H. Park, Y. J. Choi et al., "Molecular study of dietary heptadecane for the anti-inflammatory modulation of NF- $\kappa$ B in the aged kidney," PLoS ONE, vol. 8, no. 3, Article ID e59316, 2013.

[69] Y. Tang, L. Yu, Q. Pel, L. Xu, and H. Wang, "Extraction of polysaccharides from Spirulina with boiling water," Agricultural Science and Technology, vol. 15, no. 6, pp. 1043-1045, 2014.

[70] N. Pugh, S. A. Ross, H. N. ElSohly, M. A. ElSohly, and D. S. Pasco, "Isolation of three high molecular weight polysaccharide preparations with potent immunostimulatory activity from Spirulina platensis, Aphanizomenon flos-aquae and Chlorella pyrenoidosa," Planta Medica, vol. 67, no. 8, pp. 737-742, 2001.

[71] R. Grzanna, A. Polotsky, P. V. Phan, N. Pugh, D. Pasco, and C. G. Frondoza, "Immolina, a high-molecular-weight polysaccharide fraction of spirulina, enhances chemokine expression in human monocytic THP-1 cells," The Journal of Alternative and Complementary Medicine, vol. 12, no. 5, pp. 429-435, 2006.

[72] P. Balachandran, N. D. Pugh, G. Ma, and D. S. Pasco, “Tolllike receptor 2-dependent activation of monocytes by Spirulina polysaccharide and its immune enhancing action in mice," International Immunopharmacology, vol. 6, no. 12, pp. 18081814, 2006.

[73] Y. Akao, T. Ebihara, H. Masuda et al., "Enhancement of antitumor natural killer cell activation by orally administered Spirulina extract in mice," Cancer Science, vol. 100, no. 8, pp. 1494$1501,2009$.

[74] H. A. Al-Batshan, S. I. Al-Mufarrej, A. A. Al-Homaidan, and M. A. Qureshi, "Enhancement of chicken macrophage phagocytic function and nitrite production by dietary Spirulina platensis," Immunopharmacology and Immunotoxicology, vol. 23, no. 2, pp. 281-289, 2001.

[75] E. Vardaka, K. A. Kormas, M. Katsiapi, S. Genitsaris, and M. Moustaka-Gouni, "Molecular diversity of bacteria in commercially available 'Spirulina' food supplements," PeerJ, vol. 4, article e1610, 2016.

[76] D. Bhowmik, J. Dubey, and S. Mehra, "Probiotic efficiency of Spirulina platensis - stimulating growth of lactic acid bacteria," World Journal of Dairy \& Food Sciences, vol. 4, no. 2, pp. 160-163, 2009. 
[77] K. S. Uma Suganya, K. Govindaraju, V. Ganesh Kumar et al., "Blue green alga mediated synthesis of gold nanoparticles and its antibacterial efficacy against Gram positive organisms," Materials Science and Engineering C, vol. 47, pp. 351-356, 2015.

[78] A. Finamore, I. Peluso, and M. Serafini, "Chapter 41-synbiotics: a new strategy to improve the immune system from the gut to peripheral sites," Probiotics, Prebiotics, and Synbiotics: Bioactive Foods in Health Promotion, pp. 567-574, 2016.

[79] P. Malik, C. Kempanna, N. Murthy, and A. Anjum, "Quality characteristics of yoghurt enriched with Spirulina powder," Mysore Journal of Agricultural Sciences, vol. 47, no. 2, pp. 354-359, 2013.

[80] V. Fadaei, F. Mohamadi-Alasti, and K. Khosravi-Darani, "Influence of Spirulina platensis powder on the starter culture viability in probiotic yoghurt containing spinach during cold storage," European Journal of Experimental Biology, vol. 3, no. 3, pp. 389393, 2013.

[81] A. S. Akalin, G. Ünal, and M. C. Dalay, "Influence of Spirulina platensis biomass on microbiological viability in traditional and probiotic yogurts during refrigerated storage," Italian Journal of Food Science, vol. 21, no. 3, pp. 357-364, 2009.

[82] G. Z. De Caire, J. L. Parada, M. C. Zaccaro, and M. M. S. De Cano, "Effect of Spirulina platensis biomass on the growth of lactic acid bacteria in milk," World Journal of Microbiology and Biotechnology, vol. 16, no. 6, pp. 563-565, 2000.

[83] H. H. Abd El-Baky, F. K. El Baz, and G. S. El-Baroty, "Production of phenolic compounds from Spirulina maxima microalgae and its protective effects in vitro toward hepatotoxicity model," African Journal of Pharmacy and Pharmacology, vol. 3, no. 4, pp. 133-139, 2009.

[84] K. G. Mallikarjun Gouda, K. Udaya Sankar, R. Sarada, and G. A. Ravishankar, "Supercritical $\mathrm{CO}_{2}$ extraction of functional compounds from Spirulina and their biological activity," Journal of Food Science and Technology, vol. 52, no. 6, pp. 3627-3633, 2015.

[85] S. H. Mahmoud, R. M. Mahmoud, I. S. Ashoush, and M. Y. Attia, "Immunomodulatory and antioxidant activity of pomegranate juice incorporated with spirulina and echinacea extracts sweetened by stevioside," Journal of Agricultural and Veterinary Sciences (Qassim University), vol. 8, no. 2, pp. 161-174, 2015.

[86] O. M. Morsy, A. M. Sharoba, A. I. EL-Desouky, H. E. M. Bahlol, and E. M. Abd El Mawla, "Production and evaluation of some extruded food products using spirulina algae," Annals of Agricultural Science, Moshtohor, vol. 52, no. 4, pp. 329-342, 2014.

[87] M. Fradique, A. P. Batista, M. C. Nunes, L. Gouveia, N. M. Bandarra, and A. Raymundo, "Incorporation of Chlorella vulgaris and Spirulina maxima biomass in pasta products. Part 1: preparation and evaluation," Journal of the Science of Food and Agriculture, vol. 90, no. 10, pp. 1656-1664, 2010.

[88] G. Özyurt, L. Uslu, I. Yuvka et al., "Evaluation of the cooking quality characteristics of pasta enriched with Spirulina platensis," Journal of Food Quality, vol. 38, no. 4, pp. 268-272, 2015.

[89] A. C. Lemes, K. P. Takeuchi, J. C. M. de Carvalho, and E. D. G. Danesi, "Fresh pasta production enriched with Spirulina platensis biomass," Brazilian Archives of Biology and Technology, vol. 55, no. 5, pp. 741-750, 2012.

[90] P. Malik, C. Kempanna, and P. Aman, "Quality characteristics of ice cream enriched with Spirulina powder," International Journal of Food and Nutrition Science, vol. 2, no. 1, pp. 44-50, 2013.

[91] P. Malik, C. Kempanna, N. Murthy, and A. Anjum, "Quality characteristics of yoghurt enriched with spirulina powder," Mysore Journal of Agricultural Sciences, vol. 47, no. 2, pp. 354-359, 2013.
[92] M. Guldas and R. Irkin, "Influence of Spirulina platensis powder on the microflora of yoghurt and acidophilus milk," Mljekarstvo, vol. 60, no. 4, pp. 237-243, 2010.

[93] M. Løbner, A. Walsted, R. Larsen, K. Bendtzen, and C. H. Nielsen, "Enhancement of human adaptive immune responses by administration of a high-molecular-weight polysaccharide extract from the cyanobacterium Arthrospira platensis," Journal of Medicinal Food, vol. 11, no. 2, pp. 313-322, 2008.

[94] T. Hirahashi, M. Matsumoto, K. Hazeki, Y. Saeki, M. Ui, and T. Seya, "Activation of the human innate immune system by Spirulina: augmentation of interferon production and NK cytotoxicity by oral administration of hot water extract of Spirulina platensis," International Immunopharmacology, vol. 2, no. 4, pp. 423-434, 2002.

[95] H.-K. Lu, C.-C. Hsieh, J.-J. Hsu, Y.-K. Yang, and H.-N. Chou, "Preventive effects of Spirulina platensis on skeletal muscle damage under exercise-induced oxidative stress," European Journal of Applied Physiology, vol. 98, no. 2, pp. 220-226, 2006.

[96] C. H. Nielsen, P. Balachandran, O. Christensen et al., "Enhancement of natural killer cell activity in healthy subjects by Immulina ${ }^{\circledR}$, a Spirulina extract enriched for Braun-type lipoproteins," Planta Medica, vol. 76, no. 16, pp. 1802-1808, 2010.

[97] R. Shyam, S. N. Singh, P. Vats et al., "Wheat grass supplementation decreases oxidative stress in healthy subjects: a comparative study with Spirulina," Journal of Alternative and Complementary Medicine, vol. 13, no. 8, pp. 789-791, 2007.

[98] H.-J. Park and H.-S. Lee, “The influence of obesity on the effects of spirulina supplementation in the human metabolic response of Korean elderly," Nutrition Research and Practice, vol. 10, no. 4, pp. 418-423, 2016.

[99] H. J. Park, Y. J. Lee, H. K. Ryu, M. H. Kim, H. W. Chung, and W. Y. Kim, "A randomized double-blind, placebo-controlled study to establish the effects of spirulina in elderly Koreans," Annals of Nutrition and Metabolism, vol. 52, no. 4, pp. 322-328, 2008.

[100] P. V. Torres-Durán, A. Ferreira-Hermosillo, A. Ramos-Jiménez, R. P. Hernández-Torres, and M. A. Juárez-Oropeza, "Effect of spirulina maxima on postprandial lipemia in young runners: a preliminary report," Journal of Medicinal Food, vol. 15, no. 8, pp. 753-757, 2012.

[101] J. Teas and M. R. Irhimeh, "Dietary algae and HIV/AIDS: proof of concept clinical data," Journal of Applied Phycology, vol. 24, no. 3, pp. 575-582, 2012.

[102] M.-E. Ngo-Matip, C. A. Pieme, M. Azabji-Kenfack et al., "Impact of daily supplementation of Spirulina platensis on the immune system of naïve HIV-1 patients in Cameroon: a 12months single blind, randomized, multicenter trial," Nutrition Journal, vol. 14, article 70, 2015.

[103] M. Azabji-Kenfack, S. E. Dikosso, E. G. Loni et al., "Potential of spirulina platensis as a nutritional supplement in malnourished HIV-infected adults in Sub-Saharan Africa: a randomised, single-blind study," Nutrition and Metabolic Insights, vol. 4, pp. 29-37, 2011.

[104] E. Yamani, J. Kaba-Mebri, C. Mouala, G. Gresenguet, and J. L. Rey, "Use of spirul in a supplement fornutritional management of HIV-infected patients: study in Bangui, Central African Republic," Medecine Tropicale, vol. 69, no. 1, pp. 66-70, 2009.

[105] F. S. Winter, F. Emakam, A. Kfutwah, J. Hermann, M. AzabjiKenfack, and M. B. Krawinkel, "The effect of Arthrospira platensis capsules on CD4 T-Cells and antioxidative capacity in a randomized pilot study of adult women infected with human immunodeficiency virus not under HAART in Yaoundé, Cameroon," Nutrients, vol. 6, no. 7, pp. 2973-2986, 2014. 
[106] E. H. Lee, J. Park, Y. Choi, K. Huh, and W. Kim, "A randomized study to establish the effects of spirulina in type 2 diabetes mellitus patients," Nutrition Research and Practice, vol. 2, no. 4, pp. 295-300, 2008.

[107] T. K. Mao, J. Van De Water, and M. E. Gershwin, "Effects of a Spirulina-based dietary supplement on cytokine production from allergic rhinitis patients," Journal of Medicinal Food, vol. 8, no. 1, pp. 27-30, 2005.

[108] M. Ismail, M. F. Hossain, A. R. Tanu, and H. U. Shekhar, "Effect of spirulina intervention on oxidative stress, antioxidant status, and lipid profile in chronic obstructive pulmonary disease patients," BioMed Research International, vol. 2015, Article ID 486120, 7 pages, 2015.

[109] H. Beheshtipour, A. M. Mortazavian, R. Mohammadi, S. Sohrabvandi, and K. Khosravi-Darani, "Supplementation of spirulina platensis and chlorella vulgaris algae into probiotic fermented milks," Comprehensive Reviews in Food Science and Food Safety, vol. 12, no. 2, pp. 144-154, 2013.

[110] H. E. Rasmussen, I. Martínez, J. Y. Lee, and J. Walter, "Alteration of the gastrointestinal microbiota of mice by edible blue-green algae," Journal of Applied Microbiology, vol. 107, no. 4, pp. 11081118, 2009.

[111] C. D. Davis, "The gut microbiome and its role in obesity," Nutrition Today, vol. 51, no. 4, pp. 167-174, 2016.

[112] B. O. Schroeder and F. Bäckhed, "Signals from the gut microbiota to distant organs in physiology and disease," Nature Medicine, vol. 22, no. 10, pp. 1079-1089, 2016.

[113] Z.-K. Wang, Y.-S. Yang, Y. Chen, J. Yuan, G. Sun, and L.-H. Peng, "Intestinal microbiota pathogenesis and fecal microbiota transplantation for inflammatory bowel disease," World Journal of Gastroenterology, vol. 20, no. 40, pp. 14805-14820, 2014.

[114] R. J. Marles, M. L. Barrett, J. Barnes et al., "United states pharmacopeia safety evaluation of spirulina," Critical Reviews in Food Science and Nutrition, vol. 51, no. 7, pp. 593-604, 2011.

[115] E. E. Mazokopakis, C. M. Karefilakis, A. N. Tsartsalis, A. N. Milkas, and E. S. Ganotakis, "Acute rhabdomyolysis caused by Spirulina (Arthrospira platensis)," Phytomedicine, vol. 15, no. 6-7, pp. 525-527, 2008.

[116] M. Petrus, R. Culerrier, M. Campistron, A. Barre, and P. Rougé, "First case report of anaphylaxis to spirulin: identification of phycocyanin as responsible allergen," Allergy, vol. 65, no. 7, pp. 924-925, 2010.

[117] T.-M. Le, A. C. Knulst, and H. Röckmann, "Anaphylaxis to Spirulina confirmed by skin prick test with ingredients of Spirulina tablets," Food and Chemical Toxicology, vol. 74, pp. 309-310, 2014.

[118] O. Kraigher, Y. Wohl, A. Gat, and S. Brenner, "A mixed immunoblistering disorder exhibiting features of bullous pemphigoid and pemphigus foliaceus associated with Spirulina algae intake," International Journal of Dermatology, vol. 47, no. 1, pp. 61-63, 2008.

[119] A. N. Lee and V. P. Werth, "Activation of autoimmunity following use of immunostimulatory herbal supplements," Archives of Dermatology, vol. 140, no. 6, pp. 723-727, 2004.

[120] C. Di Lorenzo, A. Ceschi, H. Kupferschmidt et al., "Adverse effects of plant food supplements and botanical preparations: a systematic review with critical evaluation of causality," British Journal of Clinical Pharmacology, vol. 79, no. 4, pp. 578-592, 2015.

[121] M. Iwasa, M. Yamamoto, Y. Tanaka, M. Kaito, and Y. Adachi, "Spirulina-associated hepatotoxicity," The American Journal of Gastroenterology, vol. 97, no. 12, pp. 3212-3213, 2002.
[122] S. Savranoglu and T. B. Tumer, "Inhibitory effects of spirulina platensis on carcinogen-activating cytochrome $\mathrm{P} 450$ isozymes and potential for drug interactions," International Journal of Toxicology, vol. 32, no. 5, pp. 376-384, 2013.

[123] I. Peluso, M. Palmery, and M. Serafini, "Association of flavonoid-rich foods and statins in the management of hypercholesterolemia: a dangerous or helpful combination?" Current Drug Metabolism, vol. 16, no. 9, pp. 833-846, 2015.

[124] I. Peluso and M. Palmery, "Is a flavonoid-rich diet with steamer cooking safe during calcineurin inhibitors therapy?" Journal of Clinical Pharmacy and Therapeutics, vol. 39, no. 5, pp. 471-474, 2014.

[125] J. P. Werba, S. Misaka, M. G. Giroli et al., "Overview of green tea interaction with cardiovascular drugs," Current Pharmaceutical Design, vol. 21, no. 9, pp. 1213-1219, 2015.

[126] N. Molnár, B. Gyenis, and L. Varga, "Influence of a powdered Spirulina platensis biomass on acid production of lactococci in milk," Milchwissenschaft, vol. 60, no. 4, pp. 380-382, 2005.

[127] G. Stefani, D. Romano, and A. Cavicchi, "Consumer expectations, liking and willingness to pay for specialty foods: do sensory characteristics tell the whole story?" Food Quality and Preference, vol. 17, no. 1-2, pp. 53-62, 2006.

[128] K. G. Grunert, "The common ground between sensory and consumer science," Current Opinion in Food Science, vol. 3, pp. 19-22, 2015.

[129] R. Sachdeva, R. Kaur, and J. K. Sangha, "Effect of supplementation of Spirulina on the haematological profile and intellectual status of school girls (7-9 years)," Journal of Human Ecology, vol. 15, no. 2, pp. 105-108, 2004.

[130] E. E. Mazokopakis, M. G. Papadomanolaki, A. A. Fousteris, D. A. Kotsiris, I. M. Lampadakis, and E. S. Ganotakis, "The hepatoprotective and hypolipidemic effects of Spirulina (Arthrospira platensis) supplementation in a Cretan population with nonalcoholic fatty liver disease: a prospective pilot study," Annals of Gastroenterology, vol. 27, no. 4, pp. 387-394, 2014.

[131] K. Kaur, R. Sachdeva, and A. Kochhar, "Effect of spirulina supplementation on the nutrient adequacy and health status of noninsulin-dependent diabetes mellitus (NIDDM) male subjects," Studies on Ethno-Medicine, vol. 3, no. 2, pp. 119-126, 2009.

[132] G. Kelkar, K. Subhadra, and R. K. Chengappa, "Effect of antioxidant supplementation on hematological parameters, oxidative stress and performance of Indian athletes," Journal of Human Ecology, vol. 24, no. 3, pp. 209-213, 2008.

[133] C. Selmi, P. S. C. Leung, L. Fischer et al., "The effects of Spirulina on anemia and immune function in senior citizens," Cellular and Molecular Immunology, vol. 8, no. 3, pp. 248-254, 2011.

[134] E. E. Mazokopakis, I. K. Starakis, M. G. Papadomanolaki, N. G. Mavroeidi, and E. S. Ganotakis, "The hypolipidaemic effects of Spirulina (Arthrospira platensis) supplementation in a Cretan population: a prospective study," Journal of the Science of Food and Agriculture, vol. 94, no. 3, pp. 432-437, 2014.

[135] M.-E. Ngo-Matip, C. A. Pieme, M. Azabji-Kenfack et al., "Effects of Spirulina platensis supplementation on lipid profile in HIVinfected antiretroviral naïve patients in Yaounde-Cameroon: A Randomized Trial Study," Lipids in Health and Disease, vol. 13, article 191, 2014.

[136] A. Ferreira-Hermosillo, P. V. Torres-Duran, and M. A. JuarezOropeza, "Hepatoprotective effects of Spirulina maxima in patients with non-alcoholic fatty liver disease: a case series," Journal of Medical Case Reports, vol. 4, article 103, 2010. 
[137] R. Samuels, U. V. Mani, U. M. Iyer, and U. S. Nayak, "Hypocholesterolemic effect of Spirulina in patients with hyperlipidemic nephrotic syndrome," Journal of Medicinal Food, vol. 5, no. 2, pp. 91-96, 2002.

[138] P. Parikh, U. Mani, and U. Iyer, "Role of Spirulina in the control of glycemia and lipidemia in type 2 diabetes mellitus," Journal of Medicinal Food, vol. 4, no. 4, pp. 193-199, 2001.

[139] K. Hayashi, T. Hayashi, and I. Kojima, "A natural sulfated polysaccharide, calcium spirulan, isolated from Spirulina platensis: in vitro and ex vivo evaluation of anti-herpes simplex virus and anti-human immunodeficiency virus activities," AIDS Research and Human Retroviruses, vol. 12, no. 15, pp. 1463-1471, 1996.

[140] T. Magrone and E. Jirillo, "The interaction between gut microbiota and age-related changes in immune function and inflammation," Immunity and Ageing, vol. 10, no. 1, article no. 31, 2013.

[141] T. Magrone and E. Jirillo, "Childhood obesity: immune response and nutritional approaches," Frontiers in Immunology, vol. 6, article 76, 2015.

[142] C. J. Andersen, K. E. Murphy, and M. L. Fernandez, "Impact of Obesity and Metabolic Syndrome on Immunity," Advances in Nutrition, vol. 7, no. 1, pp. 66-75, 2016.

[143] T. Atsumi, S. Fujisawa, Y. Nakabayashi, T. Kawarai, T. Yasui, and K. Tonosaki, "Pleasant feeling from watching a comical video enhances free radical-scavenging capacity in human whole saliva," Journal of Psychosomatic Research, vol. 56, no. 3, pp. 377379, 2004.

[144] Y. Barak, “The immune system and happiness," Autoimmunity Reviews, vol. 5, no. 8, pp. 523-527, 2006. 


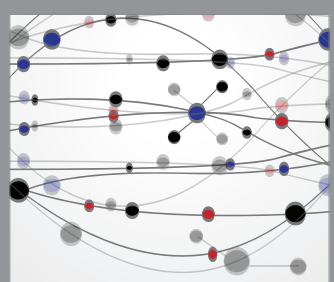

The Scientific World Journal
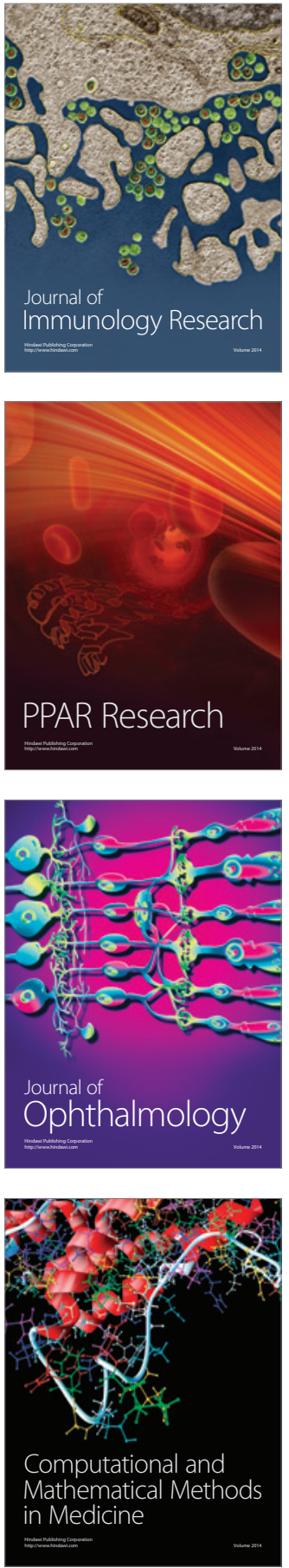

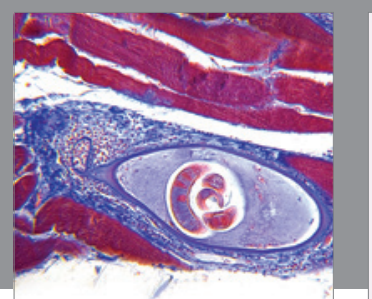

Gastroenterology Research and Practice
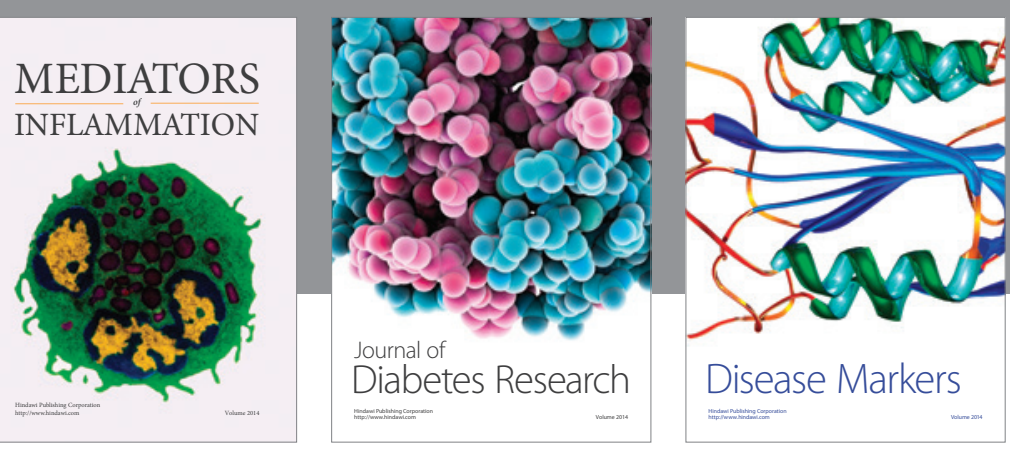

Disease Markers

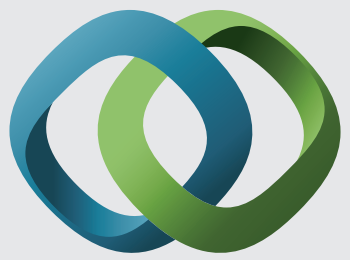

\section{Hindawi}

Submit your manuscripts at

https://www.hindawi.com
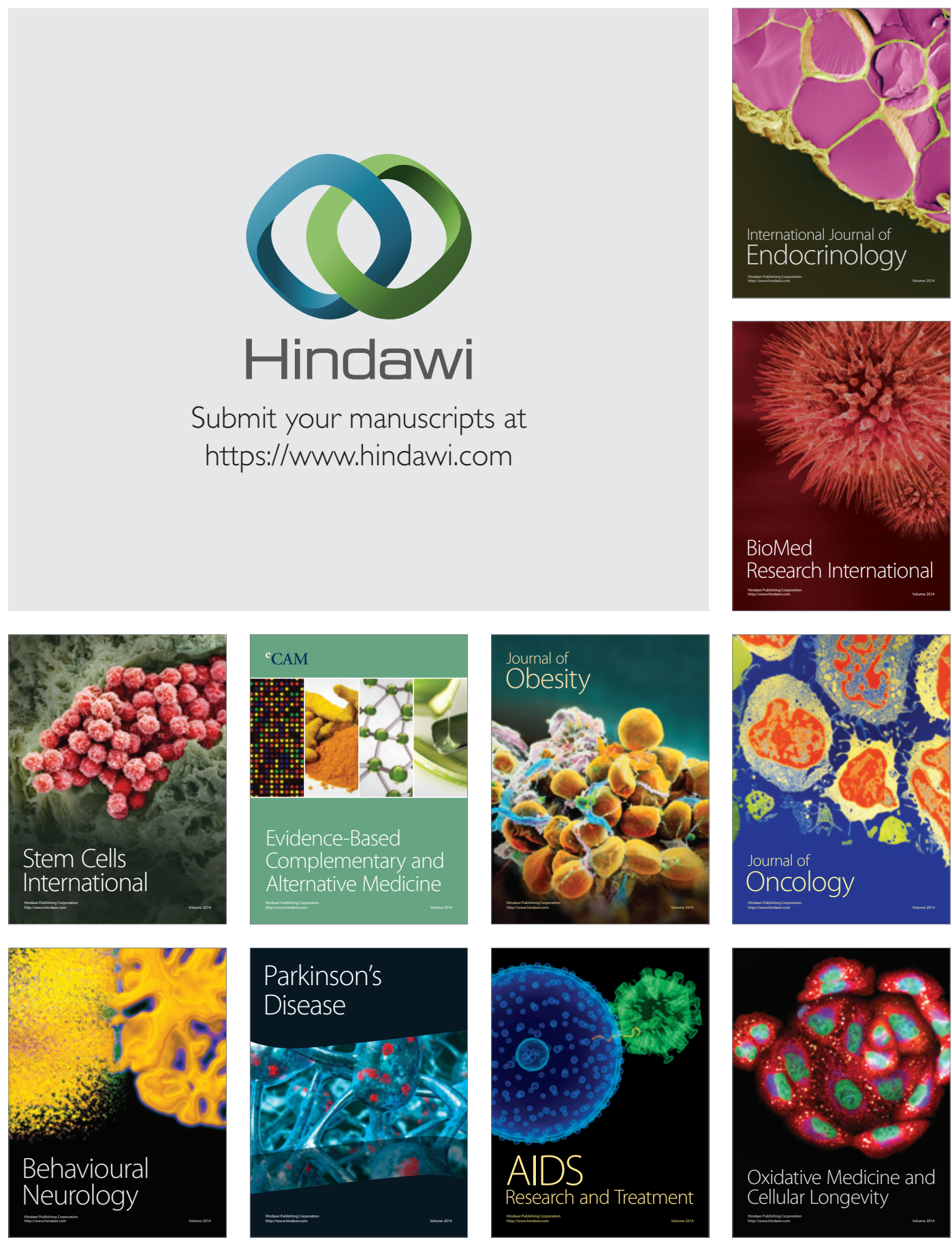